\title{
Purpose Of Art Dan Kontribusinya Dalam Transformasi Budaya (Studi Kasus: Tari Jayengrana)
}

\author{
Lilis Sumiati \\ Institut Seni Budaya Indonesia (ISBI) Bandung \\ Jl. Buah Batu No. 212 Bandung 40265
}

\begin{abstract}
Culture as elastic and dynamic properties tail on the owner of the originator of culture is no other human being. It is thus likely to undergo changes toward goals with different imaging. Truth culture, religion, science, and philosophy though, has always been the pursuit of every man in space and time bounded. Efforts to achieve cultural change sometimes clash with the culture as a tradition. A paradox between two different sides even become a conductor to immortality. Cultural changes have an impact on the lives of the various patterns of textual dance is no exception. About this manifests as dealing with creative behavior of agents based on artistic intent (purpose of art) which in each system were different.
\end{abstract}

Keywords: Culture , purpose of art, dance textual , transformation

\begin{abstract}
ABSTRAK
Tatanan budaya memiliki sifat elastis dan dinamis mengekor pada empunya pencetus kebudayaan yang tiada lain adalah manusia. Sifatnya yang demikian berpeluang mengalami perubahan menuju cita dengan pencitraan berbeda. Kebenaran budaya, agama, ilmu, dan filsafat sekalipun, senantiasa menjadi kejaran setiap insan dalam ruang dan waktu yang berbatas. Upaya menggapai perubahan budaya terkadang berbenturan dengan tatanan budaya tradisi. Suatu paradoksal antar dua sisi yang berbeda bahkan menjadi penghantar menuju keabadian.

Perubahan budaya berdampak pada berbagai pola kehidupan tak terkecuali tekstual tarian. Perihal ini mewujud karena berhadapan dengan laku kreatif para seniman yang didasarkan pada maksud seni (purpose of art) yang pada setiap sistem menganut perbedaan.
\end{abstract}

Kata kunci: Budaya, purpose of art, tekstual tarian, transformasi

\section{PENDAHULUAN}

Seni pertunjukan merupakan bagian dari kebudayaan yang dihasilkan melalui kreativitas manusia dalam mengaktualisasikan kualitas dirinya. Kebudayaan merupakan alat pemenuhan kebutuhan manusia sebagai pengguna alat itu sendiri. Suriasumantri (2010: 261) menjelaskan lebih rinci bahwa "kebudayaan diartikan sebagai keseluruhan yang mencakup pengetahuan, kepercayaan, seni, moral, hukum, adat serta kemampuan dan kebiasaan lainnya yang diperoleh manusia sebagai anggota masyarakat".

Kebudayaan hasil rekayasa manusia dalam suatu kelompok tertentu sifatnya sangat dinamis. Hal tersebut disebabkan sifat kodratinya bahwa kehidupan sebagai suatu lingkaran yang senantiasa berputar sehingga dapat dianalogikan bahwa realitas adalah proses. Proses dari setiap bentuk yang tercipta, menurut Humphrey (1951: 80-81) "selanjutnya akan melalui empat 
tingkatan antara lahir-berkembang-runtuhdan mati serta tidak ada yang dapat menahan kekuatan waktu". Pencarian jati diri dalam kebenaran yang sejati diadaptasi pada setiap jiwa zaman. Laju kehidupan tradisi perlahan, tetapi pasti merangkak menuju modern. Selanjutnya dunia posmodern secepat kilat merambah dalam setiap sel kehidupan.

Perubahan terjadi disebabkan oleh banyak faktor yang mempengaruhinya baik secara internal maupun eksternal. Faktor internal terletak pada unsur manusia itu sendiri yang memiliki insting selalu ingin berubah kepada arah yang lebih baik. Sebuah karya seni yang diciptakan seniman memuat nilai yang sifatnya sesaat. Artinya kepuasan seorang seniman tidak bisa diukur dalam waktu singkat, tetapi memerlukan perenungan panjang dan pengalaman untuk menyinergikan diri dalam kreativitas berkelanjutan. Di sisi lain faktor eksternal secara tajam selalu mendorong adanya perubahan pada setiap nafas kehidupan.

Perubahan budaya, di sisi lain, menurut Kaplan (2002: 82) "dapat diperlawankan antara konsep dysfunction (disfungsi, yakni fungsi negatif) dengan konsep function (fungsi, yakni fungsi positif)". Hal ini mengandung pengertian bahwa kegiatan suatu budaya (seni) dikatakan fungsional manakala memberikan andil bagi adaptasi atau penyesuaian sistem tertentu dan dikatakan disfungsional apabila melemahkan adaptasi tersebut.

Fungsional budaya sangat bergantung pada tindakan adaptasi dengan lingkungan. Keberadaan lingkungan sifatnya dinamis mengikuti perkembangan daya hidup manusianya. Sebagaimana halnya terjadi pada daya hidup kesenian. Proses kreativitas setidaknya berkaitan erat dengan tujuan dan maksud karya seni (purpose of art) yang diinginkan para seniman sebagai penyangga. Tindakan para seniman ini didorong untuk memenuhi kebutuhan suatu sistem yang berlaku pada setiap lingkungan. Dengan demikian perubahan pada suatu karya seni berpeluang cukup besar.

\section{METODE}

Metode penelitian menurut Ratna (2010: 85), adalah "memilih atau menentukan antara kualitatif dan kuantitatif, induktif dan deduktif, hermeuneutik, dialektik, deskriptif analitik, dan sebagainya". Merespons pendapat tersebut kaitannya dengan fenomena permasalahan yang diangkat, maka ditetapkan metode kualitatif, induktif, dan deskriptif analitik. Masalah-masalah kualitatif berwilayah pada "ruang yang sempit, variabel sederhana tetapi rumit dalam tataran konten, mempersoalkan makna, dan mempertanyakan fenomena" (Bungin, 2009: 50). Salah satu sifat dari data kualitatif adalah bahwa data itu memiliki kandungan yang kaya, multidimensional, dan kompleks. Pola induktif diterapkan dalam mengeksplanasi data, dimulai dari yang sempit sampai kepada yang lebih luas. Deskriptif analitik digunakan untuk mengetahui tekstual tarian secara diakronik.

\section{HASIL DAN PEMBAHASAN}

\section{Maksud seni (Purpose of art)}

Manusia hidup memiliki tujuan yaitu sejahtera di dunia dan bahagia di akhirat. Setiap langkah diupayakan memiliki makna yang menuju pada kebenaran agama, norma, dan adat istiadat. Dengan demikian setiap tindakan yang dilakukan manusia tidak lepas dari adanya pencapaian yang diinginkan. Perwujudan keinginan tersebut berkaitan erat dengan maksud dan tujuan yang sudah dicanangkan sebelum adanya tindakan.

Momentum ini senantiasa diterapkan dalam segala bidang tidak terkecuali dalam 
ruang lingkup penciptaan karya seni. Walaupun pada awal pembentukannya sejak abad ke 18 di Eropa, seni yang dianggap baik itu adalah seni yang disinterestedness atau "tanpa kepentingan"/"tanpa kegunaan" (Sumardjo, 2000: 92). Istilah yang cukup terkenal sering disebut dengan L'art fur l'art, artinya seni bukan berpikir tentang sesuatu sehingga seni yang demikian menolak dinilai berdasarkan konteks yang sedang berlaku.

Perkembangan seni selanjutnya diciptakan dengan memiliki nilai kegunaan bagi kepentingan masyarakat. Untuk mengakumulasi hubungan masyarakat dengan daya hidupnya diperlukan seni sebagai media penghubung. Untuk mewujudkan hubungan manusia dengan para leluhurnya digunakan media seni dalam bentuk upacara. Tujuan utama dari upacara ini beragam di antaranya untuk kesuburan, untuk keselamatan, untuk meminta hujan, dan sebagainya. Pada intinya upacara ini sebagai alat komunikasi antara manusia (dunia tengah) dan Tuhan (dunia atas).

Kebutuhan manusia berikutnya akan sangat bergantung pada jalinan komunikasi antar sesama. Pencapaian kebahagian ini diproyeksikan dalam bentuk kesenian yang berupa hiburan. Kontak fisik dan kontak batin antara pelaku seni dan penikmat merupakan ciri khas dalam dunia seni hiburan. Tidak ada batasan-batasan estetika yang sengaja dibuat aturan mainnya, semuanya serba bebas.

Kondisinya akan sangat berbeda ketika kedudukan seni difungsikan sebagai presentasi estetis. Seniman dan pelaku seni bekerja sama menata karyanya agar memiliki daya estetis yang berkualitas. Perihal ini dipersembahkan agar para apresiator mendapatkan kepuasan.

Ketiga fungsi tersebut sebagai salah satu cerminan secara umum dari tujuan seni yang dikaitkan dengan kebutuhan masyarakat. Apabila ditelisik dari faktor seni- man/pencipta seni terdapat keinginan yang diusung dari karya seni yang dibuatnya. Maksud dan tujuan (purpose of art) tersebut secara perinci dijelaskan oleh Rathus (1995: 5-23) yang memuat empat belas kriteria yaitu:

To create beauty, To provide decoration, To reveal truth, To immortalize, To express religious values, To express fantasy, To stimulate the intelect and fire the emotions, To create order and harmony, To express chaos, To record and commemorate experiece, To reflect the social and cultural contex, To protest injustice and raise social consciousness, To elevate the commonplace, To meet the needs of the artist.

[untuk menciptakan keindahan, untuk memberi dekorasi, untuk menyatakan kebenaran, untuk keabadian, untuk menyatakan nilai-nilai agama, untuk konteks imajinasi, untuk menstimulasi intelektual dan membakar emosi, untuk menciptakan harmoni dan pesanan, untuk ekspresi kekacauan, untuk merekam dan mengenang masa lalu, untuk mengekspresikan konteks sosial dan budaya, sebagai bentuk protes terhadap ketidakadilan dan kesadaran sosial, untuk mengangkat/membangun kejadian sehari-hari, untuk kebutuhan artis].

\section{Transformasi Tari Jayengrana}

Perlakuan mentransformasi tari Jayengrana oleh seniman pada setiap ruang dan waktu dipengaruhi oleh adanya suatu sistem. Sistem yang menggiring kepada laku kreatif didasarkan pada maksud dan tujuan pencapaian yang diinginkan. Oleh karena itu filosofi transformasi bentuk pada tari Jayengrana secara diakronik dari Sumedang ke Bandung akan dianalisis berlandaskan pada maksud seni (purpose of art) menurut Rathus.

Setiap agen seni memiliki kondisi yang berbeda-beda dalam menterjemahkan maksud seni tersebut tergantung pada kebutuhan sistemnya. Keberangkatan Ono dalam mengartikan sebuah seni dilandasi dengan kemampuan untuk berkreativitas, dilanjutkan dengan proses penciptaan, dan diakhiri 
dengan menghasilkan suatu produk. Sebagaimana dikemukakan oleh Rathus (1995: 4) bahwa "arti seni (meaning of art) memuat tiga aspek yakni, (1) as ability, (2) as proces, dan (3) as product (arti seni adalah sebagai kemampuan, sebagai proses, dan sebagai produk)".

Ono berkarya dalam bidang seni tari tidak lepas dari adanya suatu tujuan dan maksud yang paling pokok yaitu untuk memenuhi kebutuhan materi kursus tari. Dalam memenuhi kebutuhan tersebut sebagai sebuah produk tari tidak dapat lepas dari adanya tuntutan untuk menciptakan keindahan, untuk keabadian, untuk menciptakan harmoni dan pesanan, untuk merefleksikan konteks sosial dan budaya, dan untuk kebutuhan seniman. Dunia seni identik dengan pergumulan dalam menciptakan suatu keindahan. Demikian juga dalam seni tari, gerak-gerak disusun sedemikian rupa sesuai dengan filosofis, latar belakang cerita, gambaran tarian, karakter tarian, dan jenis tarian sebagai gagasan awal.

Proses penyusunan sampai pada menghasilkan suatu produk tarian secara ideal setiap seniman mengharapkan karyanya bisa abadi. Oleh karena itu dalam pembuatan karya sebaiknya dimiliki adanya kemampuan dalam membaca keinginan masyarakat. Masyarakat pada tahun 1940-an sedang gandrung-gandrungnya terhadap pertunjukan wayang golek (Wawancara dengan Ukanah, 8 April 2004). Fenomena tersebut ditangkap Ono dan dituangkan melalui tarian sesuai kemampuannya.

Struktur sosial pada saat proses penciptaan pada tahun 1942 legalitas dan otoritas berada di tingkat kaum menak. Realitas ini dikemukakan Lubis (1998: 49) dengan pernyataannya bahwa "kaum menak sebagai elite birokrasi tradisional adalah sebuah realita". Model kepemimpinan tradisional ini adalah "kepemimpinan seorang elite yang terkait dalam struktur kekuasaan tradisi- onal dan berakar pada struktur sosial yang tersusun berdasarkan kelahiran, kekayaan, dan status" (Lubis, 1998: 275). Kepemimpinan kharismatik kaum menak sangat berpengaruh sehingga masyarakat sangat menghormati dan menaati segala aturan yang dianjurkannya. Momen ini salah satunya terbukti ketika ada anjuran bahwa semua jajaran pemerintahan diwajibkan memiliki kemampuan dalam bidang seni termasuk menari. Jajaran pemerintahan pada saat itu tergolong sebagai kaum menak. Perihal ini kembali ditegaskan Lubis (1998: 246), "bupati Sumedang R. Tmg. Kusumadilaga pernah menganjurkan agar semua menak terampil ngibing". Oleh karena itu R. Gandakusumah (keponakan Pangeran Aria Suriaatmaja, yang dikenal dengan sebutan Aom Doyot), berperan menghaluskan dan menyempurnakan tarian ini. Tarian yang dimaksud adalah tari tayub yang berfungsi sebagai kalangenan para bupati. Sifat tarian ini bebas atau saka tanpa aturan yang baku, tergantung pada kreativitas masing-masing penari yang muncul secara spontan/improvisasi. Ada langkah penghalusan dan penyempurnaan tarian yang dilakukan Aom Doyot dengan membuat koreografi yang disusun berupa komposisi gerak dengan mempertimbangkan aspek ruang, waktu, dan tenaga. Tari tayub yang saka menjelma menjadi tari keurseus yang baku dan penuh aturan. Kemudian tari keurseus ini dikursuskan atau diajarkan kepada semua kaum menak.

Setelah kemerdekaan 1945 diraih oleh bangsa Indonesia, kesempatan Ono untuk menjelmakan karyanya mulai dirintis lagi. Karya tersebut diberi judul tari Jayengrana yang baru diajarkan pada tahun 1946. Sisasisa birokrasi tradisional yang bermuara pada kaum menak masih melekat. Ono yang bekerja sebagai camat masih memiliki karisma sebagai menak di mata masyarakat. Oleh karena itu antusias masyarakat untuk mengikuti kursus tari sangat tinggi. Aura 
positif ini masih terbawa sampai saat ini walaupun tidak setebal dahulu.

Tari Jayengrana yang berkembang di Bandung disangga oleh masyarakat akademis yang bergerak pada bidang kejuruan seni tari yakni STSI Bandung, UPI Bandung, dan SMKN 10 Bandung. Otoritas masyarakat akademis bersandar pada pertimbangan sistem. Pemenuhan tuntutan dari sistem dikelola oleh manusia yang bertindak sebagai seniman dalam spesifikasi masing-masing. Pada umumnya ketiga instansi ini mengangkat tarian untuk memenuhi materi pembelajaran. Perlakuan terhadap materi tari yang sudah disadap diadaptasi berdasarkan tuntutan kurikulum. Oleh karena itu keberangkatan pelestarian tidak hanya bersandarkan pada pola konservasi tetapi juga mengusung pola rekonstruksi dan revitalisasi.

Satu hal yang paling penting sebagai penajaman analisis adalah berpijak pada maksud seni, interpretasi, dan kreativitas. Maksud seni itu sendiri berkisar pada untuk apa, mengapa, dan untuk siapa tari Jayengrana diangkat menjadi bagian mata kuliah. Apabila maksud dan tujuan sudah diketahui arahnya, maka potensi diri dalam menginterpretasi tarian dan dituangkan melalui kreativitas merupakan bekal yang sangat penting untuk mewujudkan tujuan yang hendak dicapai.

Kondisi para seniman di Sumedang sebagai generasi penerus Ono dalam melestarikan tari Jayengrana tetap berada pada koridor mempertahan keasliannya. Berdasarkan kriteria maksud seni yang dilontarkan Rathus terdapat beberapa yang dianggap tepat di antaranya untuk menciptakan keindahan, untuk keabadian, untuk menciptakan harmoni dan pesanan, untuk merekam dan mengenang masa lalu.

Atmosfer yang menyebabkan tari Jayengrana mengalami transformasi di STSI Bandung, UPI Bandung, dan SMKN 10 Bandung disebabkan oleh aspek maksud

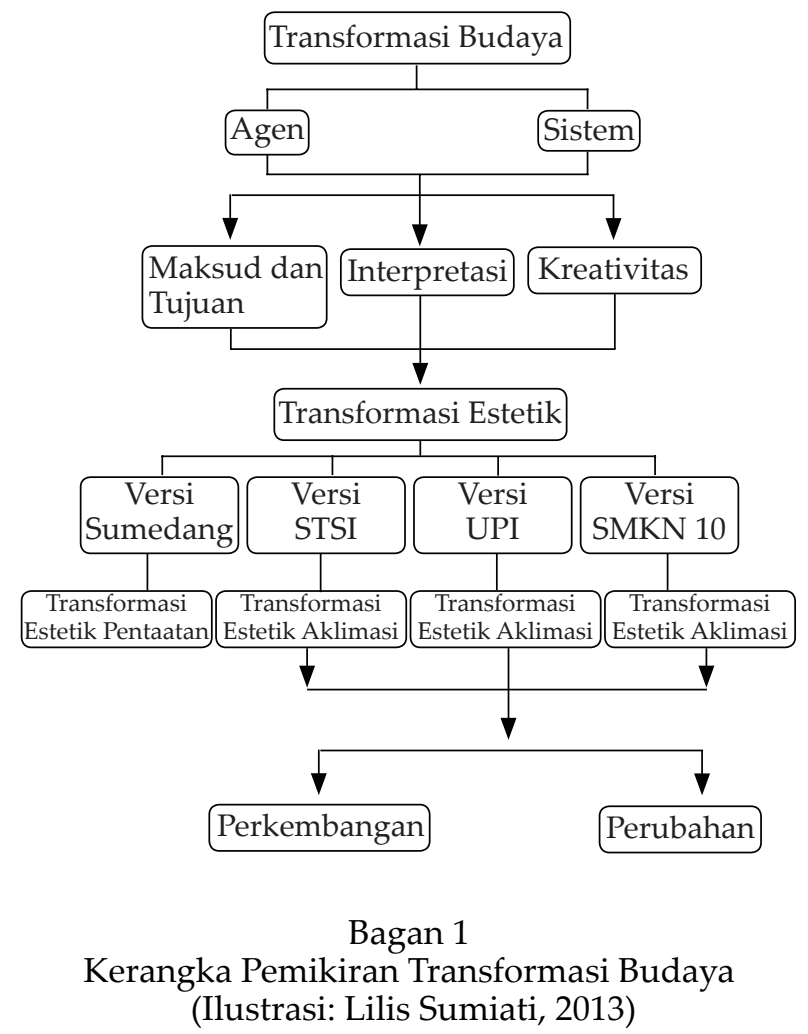

dan tujuan seni, interpretasi, serta aspek kreativitas. Dalam memenuhi tujuan seni tersebut para seniman dituntut memiliki interpretasi yang kemudian dituangkan melalui daya kreativitas. Dengan demikian kebutuhan sistem/tujuan yang ada di lingkungan masing-masing seperti tuntutan memenuhi materi pembelajaran di perguruan tinggi, tuntutan estetika, dan teatrikal pertunjukan tari di masa kini dapat tercapai.

Tari Jayengrana versi STSI mengalami transformasi dalam bentuk tari meliputi koreografi, iringan, rias, dan busana. Idealisme Rusliana yang bertindak sebagai seniman di STSI terpacu untuk mempertahankan, memodifikasi, dan mengubah bentuk tarian. Perihal tersebut dituangkan melalui interpretasi koreografi dengan mencoba memberi modifikasi pada penekanan tenaga setiap gerak, memperjelas teknik gerak, mengatur pola ruang agar dapat dikuasai secara seimbang, dan menghilangkan ragam gerak barongsay karena dianggap tidak sesuai dengan patokan satria ladak. Iringan 
menggunakan lagu tumenggungan dengan memodifikasi irama menjadi sawilet gancang. Rias dilengkapi dengan mempertegas bentuk garis alis masekon, kening pasu teleng dua, jambang godeg mecut, kumis nyiripit satria, dan hiasan pada bibir bagian bawah cedo satria. Bentuk rias ini mengarah pada konsep estetika rias wayang golek karakter satria ladak. Busana dasar menggunakan baju kutung warna hitam dengan mengubah bentuk ornamen simbar dada yang berpijak pada desain satria ladak wayang golek, celana sontog, sinjang dodot, makuta, dan soder. Aksesoris yang dikenakan terdiri dari kilat bahu, gelang tangan, sabuk, kewer, tutup rasa, tali uncal, dan gelang kaki.

Atmosfer yang menyebabkan terjadinya transformasi dilandasi faktor maksud dan tujuan. Tari Jayengrana dipilih menjadi materi dalam kurikulum Jurusan Tari di STSI Bandung berdasarkan pada pendapat Rathus di antaranya untuk menciptakan keindahan, untuk keabadian, untuk menciptakan harmoni dan pesanan, untuk kebutuhan seniman, untuk merekam dan mengenang masa lalu.

Menciptakan keindahan dalam sebuah tari merupakan suatu hal yang wajar. Mengingat tari tergolong pada bidang seni yang identik dengan ungkapan bentuk yang dipertimbangkan berdasarkan variasi, kontras, klimaks, transisi, balans, rangkaian, repetisi, dan harmoni (N.H Doubler, 1985: 148). Untuk keabadian lebih ditekankan pada pekerjaan melestarikan dan mengangkat khasanah tari wayang sebagai perwakilan dari gaya Sumedang (Wawancara dengan Rusliana, 15 Agustus 2013). Tari Jayengrana yang diadopsi pihak STSI dipertimbangkan dari aspek kualitas karakter satria ladak yang memiliki ciri spesifik sehingga dapat mewakili tari wayang Sumedang. Untuk menciptakan harmoni dan pesanan dapat diartikan pada latar belakang keberangkatan yang menjadi bahan pemikiran pihak STSI sebagai seniman yai- tu menyesuaikan dengan sistem yang tercantum dalam salah satu visi yang mengusung pada benang merah tradisi yaitu kesinambungan nilai-nilai luhur yang terus tumbuh dinamis. Untuk merekam dan mengenang masa lalu dapat diadaptasi pada pemuliaan seni tradisi agar dapat tumbuh dinamis apabila ditunjang oleh daya hidup seni yang tercantum pada misi STSI yaitu "pengembangan sistem konservasi, rekonstruksi, dan revitalisasi" (Komarudin dkk., 2011: 14-15). Realitas visi dan misi STSI di Jurusan Tari salah satunya diwujudkan pada pembelajaran tari Jayengrana sebagai perwakilan dari seni tradisi.

Dalam memenuhi kebutuhan seniman ditujukan pada wilayah interpretasi terhadap maksud seni untuk membentuk kriteria pengembangan tradisi. Tujuannya agar seni tersebut tumbuh dinamis dengan menganut sistem revitalisasi sehingga diperlukan kreativitas seorang seniman dalam menggodog tari Jayengrana berdasarkan konsep-konsep. Konsep yang dituangkan dalam proses kreatif setiap seniman/agen menurut Hawkins (1991: 15-16) melalui beberapa tahapan yaitu "sensing, feeling, imaging, transforming, and forming". Demikian halnya yang terjadi pada revitalisasi tari Jayengrana tidak lepas dari adanya proses merasakan, menghayati, mengkhayalkan, mewujudkan, dan memberi bentuk. Proses mewujudkan dan memberi bentuk dapat terealisasi setelah melewati penghayatan dan pengkhayalan. Dengan adanya proses kreatif dari seniman, tari Jayengrana versi STSI mengalami transformasi dengan cara memberikan modifikasi berupa variasi pada elemen gerak dan variasi pola tabuh pada gamelan terutama ritme sawilet yang dipercepat, agar memenuhi kriteria teatrikal sebagai seni pertunjukan masa kini. Tujuan dari transformasi ini pada dasarnya diupayakan agar dapat memenuhi tuntutan tujuan pendidikan di STSI Bandung yaitu menghasilkan sarjana seni yang memiliki 
kemampuan dan kepekaan kesenimanan dalam membaca kebutuhan zaman.

Tari Jayengrana diberikan pada semester tiga sebagai dasar pengenalan mahasiswa pada genre tari wayang. Pertimbangan ini berdasar pada tingkat kerumitan dari aspek koreografi dan iringan yang termasuk pada wilayah ritme cepat. Aspek koreografi yang menggunakan tenaga sedang dan iringan dengan bentuk irama sawilet gancang/cepat, diharapkan dapat dikuasai mahasiswa semester tiga tanpa mengalami kesulitan yang berarti. Pengertian dikuasai berarti mahasiswa mampu membawakan tarian sesuai dengan aspek kualitas menari tari wayang dan dapat digolongkan sebagai penari yang memiliki kemampuan pada tingkat "geus jadi atau utama dan madya" (Rusliana, 2012: 161).

Setiap lembaga pendidikan memiliki visi dan misi yang berbeda disesuaikan dengan latar belakang pembentukannya. Visi UPI Bandung sebagai salah satu perguruan tinggi menetapkan "sebagai satusatunya lembaga pendidikan tinggi di Indonesia yang secara konsisten berkiprah dalam bidang pendidikan" (Website UPI, http://www.upi.edu/profil/informasi/visimisi, 2013: 3).

Dalam mewujudkan visi perlu dibentuk pendamping untuk memperjelas sasaran yang berupa misi. Muatan misi UPI berkisar pada ranah menyelenggarakan pendidikan untuk menyiapkan tenaga pendidik profesional dan profesional lainnya yang berdaya saing global. Tindakan yang lebih konkret untuk mengerucutkan isi yang tertuang dalam visi dan misi adalah tujuan. Tujuan pada umumnya berguna sebagai pola tuntunan dalam menggapai citacita. Tujuan pendidikan di UPI Bandung adalah "membina dan mengembangkan mahasiswa untuk menjadi ilmuwan, tenaga pendidik, tenaga kependidikan, dan tenaga profesional lainnya yang beriman, bertakwa, profesional, berkompetensi tinggi, dan berwawasan kebangsaan" (Website UPI, http://www.upi.edu/profil/informasi/visimisi, 2013: 3).

Menggaris bawahi pernyataan tenaga pendidik dan tenaga kependidikan yang terdapat pada tujuan, memiliki perbedaan yang cukup signifikan. Sebagaimana yang dikemukakan Supriatna (Wawancara, 21 November 2013), tenaga pendidik difokuskan pada koridor profesi sebagai guru sedangkan tenaga kependidikan untuk administrasi. Hal ini berkaitan dengan jurusan tari yang ada di UPI Bandung termasuk pada bidang pendidikan yang dicetak untuk menjadi seorang guru tari.

Merujuk pada visi, misi, dan tujuan pendidikan di UPI Bandung, peluang untuk mengangkat seni tradisi dalam prodi pendidikan tari wajib dilakukan. Tari tradisi yang diangkat salah satunya adalah tari Jayengrana karya Ono. Karyati sebagai seniman dari UPI Bandung mengangkat tari Jayengrana menjadi mata kuliah sebagai upaya untuk mempertahankan dan melestarikan bentuk dan isi tari Jayengrana yang telah diciptakan Ono. Sentuhan-sentuhan variasi koreografi dituangkan dengan cara memperlambat ritme dan menyederhanakan teknik gerak. Iringan menggunakan lagu renggong gancang dengan ritme lambat. Rias menampakkan modifikasi pada bagian alis dengan bentuk masekon kandel, kening pasu teleng dua, dan jambang dengan bentuk mecut kandel. Busana dasar tetap kecuali terdapat perubahan pada warna menjadi biru terang dan bentuk ornamen simbar dada.

Kekaryaan yang dipresentasikan Ono dalam tarian ini tentunya sudah diimbangi dengan upaya menciptakan keindahan. Oleh karena itu, Karyati sebagai seniman tidak berniat untuk mengembangkan menurut daya estetisnya. Tindakan tersebut terjadi karena berpijak dalam menciptakan harmoni dan pesanan yang ada pada tujuan penyelenggaraan Perguruan Tingggi.

Bentuk upaya lainnya yaitu untuk 
mewujudkan keabadian dan untuk merekam serta mengenang masa lalu sehingga tari Jayengrana dapat dipertahankan kelestariannya. Kaitan pelestarian dengan tujuan pendidikan di UPI Bandung merupakan titik temu yang harmonis. Seniman yang bertindak menyebarkan tari Jayengrana secara utuh sesuai dengan aslinya, dianggap memenuhi syarat tujuan pendidikan. Tuntutan dan tanggung jawab seniman cukup dengan menghasilkan lulusan yang dapat menerapkan kembali materi perkuliahan kepada anak didiknya. Artinya lulusan mahasiswa UPI tidak digiring untuk memiliki skill menari dengan kualitas geus jadi (kualitas tinggi/mahir) tetapi cukup dengan derajat kemampuan geus jiga (kualitas sedang) yang setingkat dengan kriteria penari pemula dan muda.

Kondisi yang melatarbelakangi terjadinya transformasi tari di lingkungan SMKN 10 Bandung pada intinya sama dengan kondisi sistem pendidikan yang disusun. SMKN 10 Bandung merupakan sekolah kejuruan dalam bidang seni yang berada pada tingkat Sekolah Lanjutan Menengah Atas (SLTA). Visi yang ditetapkan sekolah ini adalah menjadi lembaga unggulan dalam pendidikan, pelatihan dan ketahanan seni budaya yang bermartabat tingkat nasional dan internasional pada tahun 2013. Berdasarkan visi tersebut tercipta sebuah misi yaitu menyiapkan tamatan menjadi tenaga profesional sebagai pelaku, pelatih, penata, dan pengelola seni pertunjukan tingkat menengah yang bermutu dan mampu mengembangkan diri secara berkelanjutan (Wawancara dengan Sundara, 25 November 2013).

Memperhatikan visi dan misi maka sasaran pendidikan tentunya diarahkan pada dimensi kesenimanan yang mengharapkan siswa lulusannya dapat memenuhi tuntutan pada seni pertunjukan. Dengan kata lain siswa tersebut digembleng agar memiliki skill menari yang baik dan layak untuk dipertunjukan. Kualitas kepenarian untuk tingkat SMK berdasarkan kriteria kompetensi tari Sunda tergolong pada penari pemula dan muda atau geus jiga yang berkisar pada kemampuan pengisian dan penyaluran rasa gerak dan rasa irama (Wawancara dengan Rusliana, 28 Oktober 2013).

Untuk memenuhi visi dan misi tersebut, SMKN 10 Bandung yang senimannya diwakili oleh Sundara dalam memenuhi kurikulum tari mencoba untuk mengadopsi tari Jayengrana versi STSI. Proses adaptasi dilakukan dalam beberapa pertimbangan terutama untuk memenuhi kriteria kemampuan belajar siswa jurusan tari di tingkat SLTA. Pemadatan koreografi dilakukan sebagai upaya agar motif gerak tidak terlalu menyulitkan siswa. Perubahan pola ruang dimaksudkan agar lintasannya sesuai dengan panjangnya irama musik sehingga tidak terkesan menunggu. Iringan menggunakan lagu renggong gancang dengan irama lebih lambat/sawilet kendor. Rias dilengkapi dengan mempertebal bentuk garis alis masekon, kening pasu teleng dua, jambang godeg mecut, kumis nyiripit satria, dan hiasan pada bibir bagian bawah cedo satria. Busana dasar menggunakan baju kutung warna hitam dengan mengubah bentuk ornamen simbar dada yang berpijak pada desain satria ladak wayang golek, celana sontog, sinjang dodot, makuta ketu, dan soder. Aksesoris yang dikenakan terdiri dari kilat bahu, gelang tangan, sabuk, kewer, tutup rasa, tali uncal, dan gelang kaki. Pihak seniman berusaha untuk mempresentasikan tari Jayengrana sesuai dengan kondisi kemampuan dan pengalaman siswa yang berada pada tahap penari pemula.

Dengan latar belakang tujuan yang akan dicapai, seniman tari Jayengrana dituntut aktif dan kreaktif dalam menciptakan keindahan dan menciptakan harmoni serta pesanan dengan cara menyesuaikan bentuk tarinya yang sepadan dengan kemampuan 
siswa. Tingkat kesulitan dari aspek teknik gerak, pengolahan ruang, waktu/tempo, dan tenaga harus dipertimbangkan dengan matang tanpa mengurangi ciri khas dari tariannya. Suatu manipulasi positif yaitu dilakukan pula pada bagian memperlambat irama, melakukan gerak pasif di antara gerak aktif, mengatur ruang atau arah gerak. Upaya tersebut sebagai wujud realisasi seniman dalam memenuhi kebutuhan sistem. Keberhasilan dalam memenuhi sistem berdampak pula pada capaian usaha pelestarian untuk keabadian, merekam dan mengenang masa lalu.

Filosofi transformasi bentuk pada tari Jayengrana secara diakronik dari Sumedang ke Bandung berdasarkan pada maksud seni (purpose of art) memiliki keragaman. Latar belakang keragaman ini sangat bergantung pada seniman dan sistem yang ada pada lingkungan masing-masing.

\section{PENUTUP}

Berdasarkan pada realitas data maka purpose of art menurut Rathus yang terdiri atas 14 unsur dapat terbukti sebagai pencetus terjadinya transformasi budaya. Namun demikian belum sepenuhnya mewadahi, mengingat terjadinya transformasi pada tari Jayengrana memiliki maksud lain. Dengan demikian purpose of art yang ditemukan dalam kasus transformasi Jayengrana memiliki porsi untuk menyumbang atau menambahkan teori Rathus yakni sebagai pemenuhan sistem pendidikan baik formal maupun non formal.

Dinamika estetik tari Jayengrana di STSI Bandung, UPI Bandung, dan SMKN 10 Bandung berada pada ranah transformasi estetik aklimasi. Artinya terdapat suatu tindakan penyesuaian yang berguna untuk memenuhi kebutuhan sistem pendidikan, tuntutan estetika, dan tuntutan teat- rikal pertunjukan tari di masa kini. Namun demikian dengan adanya transformasi estetik aklimasi tersebut tidak mengurangi esensi dan identitas tari Jayengrana.

Penemuan ini akhirnya menggiring terbentuknya sebuah teori konservasi yaitu pelestarian tari tradisi dapat dilakukan tidak hanya mengimitasi secara utuh tetapi senantiasa didampingi dengan tindakan modifikasi. Ranah pelestarian dan modifikasi memuat pengertian yang paradoks tetapi perlu disandingkan untuk mempertahankan keabadian. Perlu difahami bahwa pelestarian tidak cukup mempertahankan keasliannya. Mengingat keaslian bentuk/ tekstual seni belum tentu bisa seiring sejalan dengan perkembangan zaman dan masyarakat sebagai penyangganya. Oleh karena itu bentuk pelestarian perlu diubah paradigmanya dengan dua cara yakni tetap mempertahankan isi/kontekstual dan memodifikasi bentuk/tekstual seni. Modifikasi yang dimaksud mengandung arti mengubah bentuk pada bagian elemen-elemennya sehingga tidak mengurangi prinsip-prinsip bentuk yang asli.

\section{Daftar Pustaka}

Burhan Bungin

2009 Penelitian Kualitatif Komunikasi, Ekonomi, Kebijakan Publik, dan Ilmu Sosial Lainnya. Jakarta: Fajar Inter Pratama

Hawkins, Alma M.

1991 Moving from within. Chicago: A Cappella Book

$\mathrm{H}^{\prime}$ Doubler, Margaret N.

1968 Dance: ACreative Art Experience. Wisconsin: University Wisconsin Press

Humpreys, Christmas

1951 Buddhism. Penguin Book 
Iyus Rusliana

2001 Tari Wayang: Bahan Studi Kepenarian Tari Wayang. Bandung: Jurusan Tari STSI Bandung

Jakob Sumardjo

2000 Filsafat Seni. Bandung: ITB

Jujun S. Suriasumantri

2010 Filsafat Ilmu: Sebuah Pengantar Populer. Jakarta: Pustaka Sinar Harapan

Kaplan, David \& Manners, Robert A.

2002 Teori Budaya. Penerjemah: Landung Simatupang. Yogyakarta: Pustaka Pelajar

Komarudin dkk.

2011 Buku Panduan Studi. Bandung: BAA KPSI STSI Bandung

Nina Lubis

1998 Kehidupan Kaum menak Priangan 18001942. Bandung: Pusat Informasi Kebudayaan Sunda
Nyoman Kutha Ratna

2010 Metodologi Penelitian: Kajian Budaya dan Ilmu Sosial Humaniora pada Umumnya. Yogyakarta: Pustaka Pelajar

Rathus, Lois Fichner

1995 Understanding Art. New Jersey: Prentice Hall

Sumber Lain:

Website UPI,

2013 http://www.upi.edu/profil/informasi/visi-misi.

Dedi Sundara (51 tahun), Guru Jurusan Tari di SMKN 10 Bandung

Dewi Karyati (55 tahun), Dosen Pendidikan Seni Tari di UPI Bandung

Iyus Rusliana (64 tahun), Dosen dan Pakar Tari Wayang di STSI Bandung

Nanang Supriatna (55 tahun), Ketua Jurusan Seni Musik UPI Bandung 